\title{
Internationalization of higher education in Brazil: advances, obstacles, and challenges"
}

\author{
Clarissa Eckert Baeta Neves* \\ Maria Lígia de Oliveira Barbosa**
}

\begin{abstract}
In recent years, in Brazil, the theme of the internationalization of universities has become part of the agenda of academic leaders, main funding agencies and representative entities of public and private HEls. This article aims to analyze the experience of HEls and funding agencies in Brazil regarding the issue of internationalization. Starting from the process of traditional international academic cooperation, we seek to observe advances of Brazilian universities towards the definition of broader and more complex institutional strategies and objectives regarding internationalization. Drawing on concepts of the internationalization process, we briefly depict the main features of the Brazilian higher education and postgraduate system, analyzing cooperation and international influences within it. Then, we discuss the internationalization policies implemented by central government agencies and the involvement of HEls in institutional internationalization actions. It is observed that the internationalization of Brazilian higher education system is still incipient and that HEls are scarcely proactive in the development of institutional policies to receive and in leveraging the opportunities offered in the process.
\end{abstract}

Keywords: internationalization of higher education, internationalization policies, funding agencies, academic cooperation.

\footnotetext{
a Translated from Portuguese by Liana Vargas Fernandes.

* Federal University of Rio Grande do Sul, Porto Alegre, RS, Brazil.

** Federal University of Rio de Janeiro, Rio de Janeiro, RJ, Brazil.
} 


\section{Internacionalização da educação superior no Brasil: avanços, obstáculos e desafios}

\section{Resumo}

Nos últimos anos, o tema da internacionalização das universidades passou a fazer parte, no Brasil, da agenda das lideranças acadêmicas, das principais agências de fomento e de entidades representativas das IES públicas e privadas. Este artigo visa a analisar a experiência das IES e das agências de fomento no Brasil com relação ao fenômeno da internacionalização. Partindo do processo iniciado com a tradicional cooperação acadêmica internacional, busca-se observar avanços das universidades brasileiras no sentido da definição de estratégias e objetivos institucionais mais abrangentes e complexos no tocante à internacionalização. Faz-se um esboço de conceituação do processo de internacionalização e um histórico resumido dos principais traços do nosso sistema de ensino superior e da pós-graduação, analisando a cooperação e as influências internacionais no Brasil. A seguir, trata-se, das políticas de internacionalização realizadas pelas agências do governo central e do envolvimento das IES com ações institucionais de internacionalização. Constatase o caráter ainda incipiente da internacionalização do sistema de ensino superior brasileiro e a baixa proatividade das IES no desenvolvimento de políticas internas para recepção e aproveitamento das oportunidades oferecidas no processo.

Palavras-chave: internacionalização do ensino superior, políticas de internacionalização, agências de fomento, cooperação acadêmica.

\section{Introduction}

nternationalization activities have always been part of university life, whether through academic collaboration in knowledge production or professor and student mobility. However, due to changes in society and the economy during the globalization process and the constitution of the knowledge society, higher education institutions have been challenged to take on new roles, priorities, and strategies. In this context, the internationalization of universities has changed substantially over the last three decades, in response to, or as an agent of, the forces and opportunities of globalization (Knight, 2018). The internationalization of higher education is one way to 
respond to the impacts of globalization and the so-called knowledge society, while fully respecting national identity (Bernheim, 2018).

The internationalization of higher education reflects conditions peculiar to the globalization process designed until the beginning of the 21st century: The formation of a global educational market, the emergence of multiculturalism (and interculturality), and the intensification of competition in the scientific and technological research field. The global education market is seen in the expansion of demand for higher education, even in countries with still-developing higher education systems. This increases student mobility in pursuit of opportunities, while also opening an important revenue opportunity for maintaining university institutions, especially in countries where public investment is restricted (Martins, 2015).

Universities more focused on research find themselves challenged to respond to the imperative of internationalization, no more as a marginal activity, but as a commission of all university sectors. This internationalization movement in higher education starts to influence policies and actions at the system level and in institutional contexts, which impacts directly on academic life. This framework makes it relevant to analyze the different dimensions, actors, and possible consequences of this worldwide movement, also in our country.

In Brazil, the movement of the main universities towards defining strategies and pursuing broader institutional objectives regarding internationalization is very recent. There are many obstacles that need to be overcome, such as the language barrier and the public sector norms that make it quite difficult to attract foreign professors, or even to recruit Brazilian professors from other universities.

This article aims to analyze the experience of HEls and research funding agencies in Brazil regarding internationalization. Based on the process started with the traditional international academic cooperation, is it possible to observe advances made by Brazilian universities towards the definition of more comprehensive and complex institutional strategies and objectives regarding internationalization? 
In methodological terms, we conducted an analysis of documents related to internationalization policies of the main agencies and institutions involved, especially CAPES (Coordination for Improvement of Higher Education Personnel). A careful selection of documents and institutional records was made, both at higher levels of public administration and at the level of universities, in addition to considering legislation and rules for incentive to and strengthening of the implementation of institutional policies and actions. Although the mapping of initiatives by higher levels of the State and interinstitutional agencies already allows reasonable advances in the analysis, with regard to the universities such analysis is still quite exploratory.

This article is divided into five sections, in addition to this introduction. The second section provides a conceptual outline of the internationalization process. In the third section, the main features of the Brazilian higher education and postgraduate system are highlighted, while we analyze cooperation and international influence in Brazil. Next, we discuss the internationalization policies undertaken by the agencies of the central government and the involvement of HEls in institutional internationalization actions. Finally, we present our final remarks.

\section{Internationalization of higher education: a complex and changing process}

As in the case of the colossal expansion of higher education systems worldwide, the internationalization of these systems is a multifaceted social process that acquires different meanings according to the socio-historical context and is subject to a broad array of political and interpretative disputes, facing limitations and resistance and becoming a relevant resource in social confrontations. For that same reason, the characterization and analysis of the different paths for internationalization are essential and require the development of concepts that capture national specificities and allow for comparisons. Mwangil and colleagues' (2018) critical review of research on internationalization stresses the dominance of the Western university model, 
the tendency to present, in a not very explicit manner, recommendations for practical applications, and, mainly, indicates the absence in the various studies analyzed of a clear definition of the concept of internationalization.

Aiming to delimit some boundaries for the subject, we propose here Knight's more comprehensive concept, for further refinements:

Internationalization at the national, sector, and institutional levels is defined as the process of integrating an international, intercultural, or global dimension into the purpose, functions, or delivery of postsecondary education (Knight, 2003, p. 2).

De Wit and colleagues (2015, p. 29) expand Knight's definition, reinforcing the political dimension of intentionality, proposing that internationalization of higher education is

the intentional process of integrating an international, intercultural or global dimension into the purpose, functions and delivery of post-secondary education, in order to enhance the quality of education and research for all students and staff, and to make a meaningful contribution to society (emphasis in original).

According to Jane Knight (2018, p. 103) "a definition needs to be objective enough that it can be used to describe a phenomenon which is in fact universal, but which has different purposes and outcomes, depending on the actor, the stakeholder and the context". We would like to highlight the emphasis on the intentional trait of internationalization, which allows us to focus on policies, institutional actions, and strategies aimed at this purpose. If we look at the characteristics of internationalization in the past and today, we can clearly see that the internationalization process of higher education has changed over time. According to Knight and De Wit (2018), internationalization has been defined in the past as international cooperation, student exchange, studying abroad, research partnerships, binational cooperation, multicultural education etc. Currently, internationalization is linked to diverse and, in some cases, conflicting processes: globalization, regionalization, global rankings, international 
skills, double degrees, international cooperation, research networks, virtual universities, educational conglomerates, international campuses, MOOCs (Massive Open Online Courses) etc.

Altbach and Knight (2007) emphasize that, in the 21st century, the internationalization of higher education is becoming progressively complex. Increased privatization and commercialization of higher education, the growth of for-profit HEls and of regulatory agencies, new guarantees for quality, a global ranking system, international research networks, and the growing emphasis on learning results and development of skills have influenced on how the tertiary sector has been interpreting and promoting the international dimension of higher education.

While unveiling the dimensions of this complex internationalization process, several authors focus on specific issues. Thus, Kauppinen (2012) highlights activities such as study abroad programs, recruitment of foreign students, mobility of teaching and technical-administrative staff, establishment of campuses affiliated with the main institution, in addition to global partnerships between institutions. Teichler (2004), on the other hand, points to the increased frequency of activities beyond national borders, while maintaining internal systems. Yonezawa and Shimmi's (2015) study emphasizes the transformations in the forms of institutional governance.

The importance of "at home" internationalization strategies is growing. In other words, the internationalization is currently seen not only as academic mobility, but, mainly, as a process that requires the development and monitoring of strategies that will proliferate in different institutional frameworks (Knight, 2018).

Among the aspects of internationalization that take place "at home", we highlight intercultural and international dimensions incorporated into teaching and learning modes, extracurricular activities, the integration with different ethnic communities, in addition to the different forms of integration of foreign students and teachers in local academic life (Knight, 2018). This is done through changes in curricula and programs in a global cultural dimension, attracting professors and foreign students, fostering 
shared research between national and foreign researchers, extracurricular activities, international and intercultural events in local campuses etc. Emphasizing the relational dimension of the processes, in the case of abroad internationalization, academic mobility (professors and students), forms of provision of academic programs (the main aspect of integration between national and international institutions, within the space of a specific country), and the formulation and implementation of international projects (curriculum development, research, evaluation standards, e-learning platforms, professional development and training for institutional managers) are highlighted.

More and more, it is expected from universities, besides providing international academic mobility experiences, the responsibility, and the challenge of integrating international, intercultural, and comparative perspectives into students' experiences through virtual and campusbased activities. All these activities can be understood as part of the institutional positioning process within an ever more competitive and internationalized higher education system (Fumasoli et al., 2019). The goal of internationalization of higher education that has attracted the most attention has been the globalized competition for greater prestige, for more significant economic returns, and even for economic growth (Slaughter; Cantwell, 2012). Some studies also focus on the improvement of quality of education and training (Grange, 2003).

Internationalization has multiple benefits, but also risks and many unintended consequences, as indicated by several studies. Often the benefits themselves entail considerable risks. This is the case of the most obvious gain in these processes: participation in international research and debate forums, which strengthens the participation of the higher education system in the social and technological development agenda in each country and contributes to the improvement of national levels of specialized workforce qualification. At the same time, the strengthening of research tends to reinforce the academic bias of tertiary education, decreasing the perceived value of licenciaturas (bachelors' degrees focused on teaching skills) and 
technological courses and might give rise to imbalances between different training modalities.

Among the most criticized results of internationalization as a process associated with globalization (quite present in the Brazilian debate) would be the reinforcement of neoliberalism as a perverse influence in the system's organization, causing a deepening of the commercialization of higher education (Ding; Levin, 2007) and the proliferation of private institutions (Mok, 2005; Marginson, 2007). Internationalization could, through commercialization, strengthen inequalities in access to higher education, which is the main point of criticism raised by Morosini (2017).

On the other hand, well-managed internationalization policies and strategies can have important effects related to social cohesion, as indicated by Marginson (2007). The different forms of student mobility open new horizons for the beneficiaries, while also allowing the creation of networks and the increase of the essential social capital to improve the chances of access to good jobs.

Another aspect of this debate concerns the issue of values: institutional internationalization policies and actions might be criticized for inducing the pursuit of standards of knowledge production focused on the generation of patents and specific knowledge that would serve the interests of large corporations and not of a country's people. Collins and Rhoads (2010), for example, mention the neoliberal and neocolonial influence of studies encouraged by the World Bank. The contribution of internationalization to the continuity of social inequalities, to the global predominance of the English language, and, mainly, to the perpetuation of power differences favorable to the higher education systems of some specific countries, especially the United States, is also criticized (Marginson, 2007). According to authors like Buckner (2016) and Lo (2016), the dominance of a neoliberal agenda would have the effect of reducing the perception of social inequalities, especially regarding race and gender, while, at the same time, minimizing or canceling the interests and agendas of marginalized groups. 
From the point of view of values, however, Walker (2009) shows that the globalized discussion of the concepts of power, privilege, domination, marginalization, hegemony and inequality in higher education allows greater awareness and a better understanding of the effective meaning of these processes. Furthermore, from a practical point of view, internationalization, even when based on the dominant Western model of the university system, eventually offers alternatives and expands tertiary education options worldwide (Zeleza, 2012).

While the available literature, at the national and international levels, does not allow going beyond the systematization already proposed by Jane Knight, the concept of internationalization remains a challenge. Some traits are essential. The first one is that internationalization is a process of intentional change. This means that it can be the subject of policies and decisions or institutional actions, which is the starting point of the research on the subject and the focus of this article. Research on how this process would develop in countries away from the centers or successful models of internationalization. The focus on a country such as Brazil, specifically on its internationalization policies, could contribute to the conceptual debate. As Brandenburg and De Wit (2011) have shown, the goal of internationalizing has become a norm, a standard, no longer representing institutional innovation. Even more, it could enable to analyze the degree of effective agency of higher education institutions in a country, so that to understand the extent to which government policies in this field are translated into strategic responses by those, and to confirm if, and how, the strategic positioning of these institutions may or may not redefine the internationalization process within the higher education system (Fumasoli; Huisman, 2013). Thus, understanding and analyzing the plans for creating internationalization activities and connections to understand the reasonings and meanings attributed by the different actors involved, would allow us to contribute to the specification of better concepts and measures of internationalization in national contexts. 


\section{The higher education system in Brazil and the internationalization process}

An international dimension of universities is, in a way, an imperative, due to the very classic definition of these institutions. Knowledge and science have no boundaries. Culture is an experience that is enriched by contact between peoples. The training of human resources, even if focused on the specific realities in which universities are inserted, is impregnated by knowledge and cultural diversity.

The development of higher education educational systems in former colonial countries, such as Brazil, to a greater or lesser degree, has always mirrored the original experiences, and has always been nourished by the contact with and support of metropolitan institutions. When looking at the aspects of the Brazilian university system formation process, one must not neglect the international influences that were important in the constitution of this higher education system. The initial period was marked by international cooperation, and it is distinct from what is currently understood as the internationalization of universities, comprising three stages: a first one, of unsystematic, individual, and sporadic cooperation; a second one, of more organized cooperation with government investments; and a more recent one, of deepening of interinstitutional relations and more defined agreements (Stallivieri, 2017).

Then, we seek to analyze the various forms of international cooperation that contributed to the constitution of the Brazilian higher education system and of internationalization policies in the strict sense, highlighting the role of agencies and post-graduate programs.

* Term referred to the predominant presence of people (mostly men) with Bachelors' law degree in the political and cultural spheres in the country. (N.T.) 


\section{The constitution of the Brazilian higher education system and international influences}

The presence of the international academic community was fundamental for the emergence of the first universities in Brazil. Through academic mobility, during that period, foreign professors came to Brazil to teach and help in the structuring of the newly created Brazilian universities. An example of this was the evident renewing spirit of higher education with the creation of the University of São Paulo in 1934. The aim was to break with stagnant bacharelismo* in the country and revitalize higher education. The creation of the Faculty of Philosophy, Sciences, and Languages, which had foreign research professors, mainly from Europe, played a fundamental role in this process (Schwartzman, 2001; Neves, 2017).

The 1950s, when the importance of human resources for economic and social development was recognized following Europe's experience of reconstruction after the war, sparked government initiatives in Brazil seeking to improve the educational system in general and to stimulate research. In this context, scientists from the Brazilian Academy of Sciences (established in 1916) made efforts to promote scientific development in the country. In 1948, the nonprofit Society for the Progress of Science was founded, aimed at defending scientific and technological advancement and educational and cultural development in Brazil. In 1951, the National Research Council (CNPq) was created, with the purpose of promoting the development of scientific and technological research through the provision of resources to universities, laboratories, and research centers. Also, in 1951, the National Campaign for the Improvement of Higher Education Personnel (which later became CAPES) was created to meet the needs for improvement and training of human resources in Brazil. This agency should also guarantee specific resources for the training of scientists and researchers in the academic environment. Still during this period, through the initiative of American foundations, Brazil benefitted from academic missions that aimed to encourage the formation of scientific research groups (for example, in the 
fields of biology and health and human sciences). The Rockefeller Foundation (between the 1940s and 1950s), the Ford Foundation (between the 1960s and 1980s), and the Fulbright Commission (since 1957), among others, started offering scholarships for Brazilian students to take training courses abroad, in addition to incentives for research and scientific cooperation between Brazilian and American universities (Schwartzman, 2001).

In an effort to create modern institutions of higher education, in 1968, a university reform (UR) was carried out, recommending the implementation of postgraduate courses (master's and doctorate) and human resources training policy, aiming to develop the national scientific and technological potential. Postgraduate programs were a tool for consolidating research universities. The UR determined the inseparability of teaching and research and established university autonomy.

The democratic opening and the end of the military regime (19641985) marked the year of 1985. In 1988, the new Federal Constitution was promulgated. The current structure of higher education in Brazil has been formalized and standardized in the Federal Constitution and the Lei de Diretrizes e Bases Nacional (National Guidelines and Bases Act) of 1996 (LDB) and in a series of official decrees and resolutions of the National Council of Education.

With the development of postgraduate programs, a profound renewal of Brazilian higher education occurred, which led to the institutionalization of research activities in universities. International academic and technical cooperation played an important role in changing this scenario. Under the coordination of CAPES, the agency responsible for postgraduate policies and for the consolidation and expansion of stricto sensu postgraduate courses (master's and doctorate degrees) in all states of the Federation, the National Postgraduate Plans (PNPGs) were a crucial factor in establishing the architecture and development of this system. Since the mid-1970s, there have been five PNPGs. Little by little, postgraduation has been established, with the concurrent creation of specific policies, the allocation of resources and the permanent mobilization of the nascent community of researchers. 


\section{Postgraduate studies and international cooperation in Brazil}

Postgraduate studies grew and became an initiative that permanently defied the conservative atmosphere in Brazilian universities. Fundamental to this process was the inauguration, in the mid-1970s, of a regular procedure for evaluating the performance of master's and doctoral courses, overseen by CAPES. This assessment measured the results and pointed out new horizons for postgraduate studies. Nevertheless, the evaluation of postgraduate programs has eventually lost its challenging character and fell in line with a conservative dynamic typically present in Brazilian universities. In the early 1990s, the results of the evaluation of postgraduate programs no longer showed significant distinctions and had lost the power to direct the system towards constant qualitative change. In 2001, there was a change that established a new grade scale for the courses and stipulated that the higher levels of this scale would be reserved for courses that met international standards of excellence. In the proposal for the new evaluation model, greater responsibility was attributed to each field in defining which would be the indicators of excellence and, secondly, that each field should incorporate another fundamental component, namely the international trait of that excellence (CAPES, 2002).

The issue of international comparability of performance and the international integration of research groups and postgraduate courses became constant in Brazilian academic debate. Thus, CAPES started to stimulate the international integration of postgraduate courses, aiming at a more symmetrical international cooperation between institutions and programs.

Three proposals, which aimed at the creation of joint research projects and supported international exchange, in both directions, of research professors and postgraduate students, stood out: (a) the COFECUB program, in partnership with France, which started in 1978; (b) the partnership program with the British Council, of England, which started in 1988; (c) the PROBRAL Program, in partnership with Germany (DAAD), which was signed in 1994. In that year, there were around 79 projects in progress. 
Furthermore, CAPES kept offers of internships abroad and doctoral and postdoctoral scholarships constantly available. According to CAPES 19932002 administration report, the management was committed to expanding and improving international cooperation:

Our intention was to multiply the number of Brazilian groups interacting systematically with foreign groups and, in this process, to strengthen the idea of symmetry, the idea of a balanced mobility between Brazilian students and professors, and foreign students and professors, in both directions. This cooperation effort should lead to new modalities, which are the partnerships between graduate programs (CAPES, 2002, p. 11).

The effort to increase international cooperation was maintained and expanded in the $5^{\text {th }}$ PNPG and in the current one (2010-2020). Different training modalities had financial support from CAPES/CNPq, such as full doctorate degrees abroad, interuniversity exchange doctorates, double degrees, binational doctorate, and the sponsoring of participation in scientific events abroad. CAPES has also supported Joint Research Projects ${ }^{1}$ and University Partnerships ${ }^{2}$. CNPq also supports joint research projects and researcher mobility (CAPES, 2010, p. 233-240) ${ }^{3}$.

According to CAPES, during this period there was a growing institutional recognition of the importance of international integration. The Committee on International Cooperation was created (1995) for supporting the postgraduate programs and, later, a Board for International Relations (2007) was formed. Along with these, cooperation initiatives with international development

1Joint Research Projects with Brazil's main partners were promoted, including the United States, England, France, and Germany, and neighboring countries, especially Argentina. For example: Germany (PROBRAL, BRAGECRIM); Argentina (MINCYT); Cuba (MES/CUBA); Spain (DGU); USA (CAPES/UT); France (COFECUB); Portugal (GRICES/FCT); Netherlands (Univ. Wageningen); Uruguay (Univ. de La República).

${ }^{2}$ Different University Partnerships were also developed and promoted, such as: USA (FIPSE); Germany (UNIBRAL); Argentina (CAPG BA; CAFP); France (BRAFITEC; BRAFAGRI; STICAmsud; MATH-Amsud).

${ }^{3} \mathrm{CNPq}$ supports joint research with countries in South America (PROSUL) and Africa (PRÓAFRICA), training of foreign human resources in Brazil (PEC-PG, CNPq/TWAS Agreement, and $\mathrm{CNPq}$-Mozambique Scholarship Program), and the cooperation with emerging countries, based on joint R, D\&I programs (IBSA, Brazil-India-South Africa). 
agencies capable of expanding academic cooperation opportunities for postgraduate courses and research groups were multiplied. This evolution did not occur seamlessly for all institutions of the university system. It would be more correct to say that the pattern of asymmetric cooperation persists and coexists with advanced experiences of balanced and symmetrical relationships.

\section{Internationalization policies in Brazil and Brazilian HEls}

The issue of internationalization of universities became part of the agenda of academic leaders, the main development agencies, and entities representing public and private HEIs. Development agencies such as CAPES/CNPq and the Research Support Foundations (RSF) simultaneously sustain support programs for academic cooperation, seeking to expand the inclusion of students, researchers, and professors from Brazilian universities in international networks and in joint research projects. This has mainly benefited groups linked to postgraduate programs.

However, it should be noted that the conservative inertia ${ }^{4}$ of universities is only broken by external initiatives, usually by public policies that associate changes with regulatory requirements or targeted investments. In this sense, the Student Exchange Programs, the Science without Borders Program (SwB), and the CAPES/Print Program exemplify the action of external agencies.

\section{Internationalization policies}

Through an initiative by the Ministry of Foreign Affairs, with support from CAPES and CNPq, Brazil has maintained specific programs designed to support students from Latin American and African countries in undergraduate courses (Undergraduate Student Exchange Program - PEC/G) since the

\footnotetext{
${ }^{4}$ By conservative inertia in universities, we mean a resistance to change, through a constant defense of views on academic work that reproduce and crystallize formal structures of merit. However, this is a theme that deserves further investigation, seeking to unveil the social processes involved in the implementation of public policies, the values, reasons, expectations and forms of action and decision of the different participating actors.
} 
mid-1960s and for master's and doctorate degree in the country's HEls (Postgraduate Student Exchange Program PEC/PG) since the 1980s. These programs are a response to the policy fostering approaching to countries of these two regions, aiming at strengthening academic ties in the so-called global south. Over the past twenty years, many students supported by these programs have completed their studies in Brazil.

The Undergraduate Student Exchange Program (PEC/G) was created in 1965 and updated in 2013. Currently 59 countries are part of the program: 25 from Africa, 25 from the Americas, and nine from Asia. Between 2000 and 2019, 7,991 scholarships were granted to African countries, with the largest number of scholarships used by Cape Verde and Guinea Bissau; 2,592 scholarships were granted to countries in Latin America and the Caribbean, especially Paraguay, Honduras, and Peru; 87 scholarships were granted to Asia, particularly East Timor (Brasil, 2019a).

The PEC-PG Program was created in 1981 and updated in 2016. Currently, 60 countries participate in the program: 26 from Africa, 25 from the Americas, and nine from Asia. Between 2000 and 2019, 2,060 scholarships were offered to Latin America, especially Colombia and Peru; 870 scholarships were granted for Africa, mainly to Mozambique and Cape Verde; and 97 were offered to Asia, especially East Timor and China (Brasil, 2019b). This experience, however, has not generated institutional policies for attracting and accommodating foreign students and, even less, for creating organized communities of former scholarship students in their countries of origin. The HEls have only reacted to the existing demand they receive or that arises spontaneously.

The Science without Borders Program (SwB) intended to be of great impact in the context of internationalization. Its most visible feature was the international mobility of thousands of undergraduate students from technological and biomedical fields for stays in foreign academic centers, of candidates for doctoral stay or full doctorate in foreign universities, and of post-doc and senior researchers in foreign universities and research centers. A great movement was triggered, and great investments were made. 
Created in 2011 (Decree n. 7,642) by the federal government, along with the Ministry of Education (MEC) and the Ministry of Science, Technology, and Innovation (MCTI), the SwB Program had as its main goal to train and educate, in universities of excellence, highly qualified people, in addition to attracting talented youth and highly qualified foreign researchers to Brazil, in fields of knowledge defined as priorities (Brasil, 2011). The SwB Program ended in 2017 after having invested BRL 13.2 billion between 2011 and 2017. Between 2011 and 2016, 101,446 scholarships were awarded. The undergraduate stay modality represented $77.85 \%$ of the program's granted scholarships, considering the two funding agencies Capes and $\mathrm{CNPq}$. Among priority fields, engineering and other technological areas stand out, representing $44.5 \%$ of scholarships, followed by biology, biomedical, and health sciences, with $18.05 \%$ of the total number of scholarships. The reception of foreigners in Brazil represented only 2.93\% of the grants, with a total of 2,971 researchers. The 10 most sought-after countries were the United States, followed by the United Kingdom, Canada, France and Australia, Germany, Spain, Italy, Ireland, and Hungary.

In the analysis of the SwB Program, another point that stands out is the sheer volume of invested funds. As there was no measurement of results and monitoring of program performance, the program's cost-benefit ratio, both for higher education and society, is unknown. It is worth mentioning a study by Vieira (2019, p. 56) on the Science without Borders Program, in which she highlights positive aspects, such as training (although not always systematic) of a large number of students and researchers, the start of negotiations with countries with which Brazil did not have a tradition of joint research, greater visibility for Brazilian research, the creation of the "Language without Borders" program, greater reflection on the undergraduate curriculum, and the scope of granted benefits, covering all regions and states of the country. Among the negative points, she points: too high an investment to train 100,000 students and researchers; universities were not fully in control, since the students decided where they would like to study; the usage rate of credits obtained in studies abroad in Brazilian HEls was lower than 
expected; poor command of the foreign language by the students; lack of performance indicators; a higher concentration of granted scholarships in few Brazilian regions and states; poor monitoring of the students abroad and of the results of the exchange experience; a large number of undergraduate students were referred to low-qualified university institutions, especially in the United States; unachieved goals in fostering foreign visiting professors.

The results were more striking abroad than in the national university and research system itself. The program generated academic mobility from Brazil to other countries (much less in the other direction) on an unprecedented scale but showed weak institutional commitment and low impact on the dynamics of our universities and research centers. McManus and Nobre (2017, p. 785) emphasize that:

SwB was an innovative experience and leaves us many lessons. The internationalization of Brazilian universities requires the international mobility of faculty and the student body seen in the program, but higher education institutions in Brazil need to be more actively involved in this process for it to be more sustainable and so that long-term partnerships can be cultivated with foreign partners.

Finally, the public policy itself did not always achieve institutional commitment by universities to the program's goals. Nevertheless, the SwB program expanded academic mobility, even if not permanently. Universities realized that, in some way, they needed some kind of institutional reaction. Large universities in particular, due to the volume of students involved, had to organize themselves for the implementation of the program. A movement for strengthening offices for international cooperation in universities and the involvement of representative bodies was initiated ${ }^{5}$ (Maillard, 2019).

CAPES resumed its central role and launched the PrInt program in 2017, a response to the problems of $\mathrm{SwB}$ and a challenge to universities to take up the internationalization of graduate studies and research as an objective

${ }^{5}$ For example: Coimbra Group of Brazilian Universities; Association of Universities of the Montevideo Group; National Association of Directors of Federal Institutions for Higher Education. 
and long-term institutional commitment. Among the objectives of PrInt, the following stand out: promoting the consolidation of strategic plans for the internationalization of institutions; stimulating the creation of international research networks; expanding actions to support internationalization in postgraduate courses; promoting the mobility of professors and students linked to stricto sensu postgraduate courses with international cooperation; fostering the transformation of participating HEls into an international environment (CAPES, 2017).

The PrInt program thus shifted the focus from undergraduate courses, serving to rethink actions in the field of internationalization. This required the universities to have a strategic planning, for example, for choosing partners, defining related research fields, internationalizing the curriculum etc. Altogether 36 universities had their internationalization projects approved, out of 565 proposals, with 197 strategic subjects, in partnership with 1,302 institutions from 86 countries (CAPES, 2018). It is worth noting that the proposal of the PrInt program was developed due to the difficulties faced by the country in terms of global research: poorly placed in terms of its research production and the historically low impact of its publications. On the other hand, there are indications of success since there has been a measurable increase in publications and patents, in addition to a greater range of citations of Brazilian authors (Fabrizi et al., 2016; Frenken et al., 2010; Hird; Pfotenhauer, 2017; Cross; Thomson; Sinclair, 2017). The PrInt program, despite the quality and scope of the proposal, however, might be compromised if (a) severe budget constraints occur and (b) adjustments are not made to the evaluation process, so that to better define appropriate indicators to measure the international performance of graduate programs.

These programs systematize the proposals for internationalization policies designed by the federal government, providing the political orientations underlying the concepts of higher education, scientific research, and global academic integration in force in each government. They also make it possible to assess the scope and limits of each proposal, as shown by several studies, almost all of which focus on the analysis of Science 
without Borders. As Pires (2019) shows, public policies are translated into social implementation processes, within which the initial proposals can be reworked, producing effects that differ from those expected. They can also be developed more or less intensely, more or less efficiently, than what has been proposed. In the case of internationalization policies, it is no different.

\section{The internationalization process of universities in Brazil: limits and achievements}

Next, we present some data on the internationalization of universities in Brazil that allow us to assess the intricacies of implementing these policies. Data from the 2018 Higher Education Census show that the presence of foreign students in Brazilian HEls is still quite small. In 2018, Brazil had 13,398 foreign students, which is fewer than in 2015, representing only $0.184 \%$ of total enrollments (INEP, 2018). This contingent is basically composed of students from Portuguese-speaking African countries and South American countries, beneficiaries of the PEC-G and PEC-PG Programs.

This is an essential dimension of the internationalization process and the data presented suggests that there are significant deficiencies in the control, selection, direction, and support of students, as well as a lack of institutional work to attract them. It is worth noting that, besides the evaluation of postgraduate programs - requiring from the most qualified ones a systematic effort to include foreign researchers and students - and of programs such as CAPES PrInt, there is no clear policy for urging institutions to invest in the possibilities of attracting foreign professors, researchers, and students. The table 1 below lists internationalization proposals that are registered in some way on university websites or mentioned by FAUBAI ${ }^{6}$.

${ }^{6} \mathrm{FAUBAI}$, Brazilian Association of International Education. 
Table 1 - Universities with internationalization programs

\begin{tabular}{|c|c|c|c|}
\hline Region & State & $\begin{array}{l}\text { Total number of } \\
\text { universities }\end{array}$ & $\begin{array}{c}\text { Universities with } \\
\text { internationalization programs }\end{array}$ \\
\hline \multirow{4}{*}{ Southeast } & SP & 56 & 44 \\
\hline & RJ & 25 & 16 \\
\hline & MG & 33 & 23 \\
\hline & ES & 4 & 3 \\
\hline \multirow{3}{*}{ South } & RS & 26 & 25 \\
\hline & PR & 24 & 22 \\
\hline & SC & 18 & 14 \\
\hline \multirow{7}{*}{ North } & $A C$ & 1 & 1 \\
\hline & $\mathrm{AM}$ & 6 & 4 \\
\hline & AP & 2 & 1 \\
\hline & $\mathrm{RO}$ & 3 & 2 \\
\hline & RR & 2 & 1 \\
\hline & PA & 6 & 5 \\
\hline & TO & 5 & 3 \\
\hline \multirow{5}{*}{ Northeast } & MA & 6 & 4 \\
\hline & $\mathrm{AL}$ & 5 & 4 \\
\hline & BA & 13 & 12 \\
\hline & CE & 16 & 14 \\
\hline & PE & 5 & 5 \\
\hline \multirow{4}{*}{ Midwest } & DF & 6 & 6 \\
\hline & GO & 6 & 4 \\
\hline & MT & 5 & 2 \\
\hline & MS & 6 & 5 \\
\hline Total & & 279 & 220 \\
\hline
\end{tabular}

Source: Prepared by the authors ${ }^{7}$, extracted from individual universities websites and FAUBAI, 2019.

The table - which may be incomplete, since institutional sites do not always have adequate maintenance and complete information - shows

${ }^{7}$ We thank the research work on universities sites done by Claudia Oliveira, from LAPES. 
that the vast majority of Brazilian universities (78.85\%) develops some type of internationalization activity, or, at least, registers proposals in this area. These activities are greatly varied, ranging from very sophisticated programs (research, exchange of professors and students) to language courses, or even just a partnership with a Spanish bank. Several institutions have an internationalization department without mentioning specific programs or activities. Most universities have created international relations offices or secretariats (in general, linked to the dean's office) to coordinate internationalization activities, foster, articulate, and manage the university's cooperation with other institutions and nations. Examples can be found at the most qualified universities (internally and externally): University of São Paulo (USP) - Agency for National and International Academic Cooperation (AUCANI); Federal University of Rio de Janeiro (UFRJ) - Directorate of International Relations (DRI), linked to the Dean's Office of UFRJ; Federal University of Minas Gerais (UFMG) - Internationalization Committee; Federal University of Rio Grande do Sul (UFRGS) - International Relations Secretariat (RELINTER); Federal University of Santa Catarina (UFSC) - International Relations Secretariat (SINTER); Federal University of Pernambuco (UFPE) - Directorate of International Relations (DRI).

It is worth mentioning that, in 1988, university managers who had any initiative in the area of international cooperation had already launched "the proposal to create a forum, of a permanent character, that would have a scope and representation at the national level, and that could assist in carrying out activities in favor of strengthening international cooperation actions" (Stallivieri, 2004, p. 3). Thus, the Forum of Brazilian Universities Advisors for International Affairs (FAUBAI) was created. In 2014, the Forum was renamed Brazilian Association for International Education, but keeping the original acronym. FAUBAI (2019) seeks to "promote the integration and training of managers in the international field through seminars, workshops, and regional and national meetings, in addition to disseminating the diversity and potential of Brazilian HEls to development agencies, diplomatic representations, international organizations and programs." Currently, more than $200 \mathrm{HEls}$ 
from all regions of the country are associated with FAUBAI; $65.3 \%$ are universities (Zicman, 2018).

Other important data for understanding the internationalization framework comes from research conducted by CAPES in 2016. CAPES sent a questionnaire to $430 \mathrm{HEls}$, of which $110 \mathrm{HEls}$ did not respond, while 312 questionnaires contained usable responses and could be analyzed (CAPES, 2017). Based on the results of the query and the crossing of this information with the questionnaire data, the HEls were grouped into two distinct sets: Grouping 1 - 198 HEls. Although having a higher number of institutions, this grouping shows fewer postgraduate programs per $\mathrm{HEI}$, and the internationalization rates are lower (fewer implemented scholarships, agreements, projects etc.); Grouping 2 - 48 HEls. This group has fewer institutions, but there are more postgraduate courses per institution and a rate of $100 \%$ use of grants from CAPES Abroad Doctoral Stay Program/ PDSE. These HEls make better use of the fostering opportunities offered, which is reflected in a greater number of implemented scholarships, a greater number of international cooperation agreements and a greater number of projects.

Some results deserve to be highlighted. The HEls analyzed in the second grouping were at different stages of the internationalization process, which was no longer incipient. There have been international partnerships, exchanges, cooperation, joint production (albeit modest); professors were sent for postdoctoral studies abroad; doctors trained in doctoral stays abroad; double degree experiences etc. However, the internationalization of Brazilian HEls is still in its infancy when it comes to internal institutional parameters, regardless of the grouping. The country has a strong tendency to passive internationalization, with low rates of attraction of international researchers, international students, joint international programs (courses). The staff is not fluent in other languages and courses are not offered in other languages. Thus, there are few initiatives, and the mapping of these actions is hampered both by the lack of a clear definition of the policies and by some resistance to and misunderstandings about them. 
However, it can be considered that this is a dynamic scenario since the attraction of foreign visiting scholars seems now to be among the priorities of the internationalization process of HEls. Even so, the way knowledge obtained abroad is disseminated and used internally is somewhat inadequate, considering, for example, the few publications and low use of articles from international scientific journals by Brazilian professionals.

Most HEls that answered the questionnaire considered their own internationalization levels either low or moderate (70.3\%), while only eight institutions declared themselves highly internationalized. Among the institutions that are little and moderately internationalized, 52.5\% do not have an internationalization project that is part of the Institutional Development Plan. In addition, $65 \%$ of the HEls require consultancy to build this plan.

The country with the highest percentage of cooperation cited by the institutions was the United States, followed by France, Germany, the United Kingdom, and Canada. Among the least significant are South Korea and Russia. It is interesting to note that Portugal is the country with the highest percentage of applications for doctoral scholarships (25.4\%). For PDSEs (doctoral stays), the USA leads the requests, followed by Portugal. But Portugal is not a country mentioned among the five most cited by HEls as an international partner for research. This raises important questions about one of the critical axes of the conceptual discussion on internationalization, which would be the predominance of the English language (Crose, 2011; Paiz, 2017).

The most used individual scholarship program was the doctoral stay (doutorado sanduíche) (35.7\%). Although all institutions in the country receive this type of scholarship, about $24 \%$ stated that they do not participate in any CAPES program. The data on the use of PDSE quotas for the year 2016 show that $65 \%$ of these institutions (164 HEls) have not implemented the quotas made available. When asked about funding modalities (types of scholarship or cooperation projects) that the HEls consider to be priorities in their internationalization process, in Grouping 1, a significant portion 
(40\%) answered that they would be individual PDSE (doctoral stay grants), while in Grouping 2, the same portion (40\%) mentioned that the priority is incentives for teachers, followed closely (38\%) by a second priority, which would be projects, agreements or partnerships. The research also showed that undergraduate programs are not a priority for the promotion of an internationalization program for HEls, since, at first, HEls indicate other priorities, such as exchange of professors, doctoral stays, and foreign visiting professors.

Another survey reveals that Brazilian researchers with international experience collaborate with academics from around the world. Between 2013 and 2018, Brazilians co-authored works with researchers from 205 countries, which represented approximately one-third of all Web of Science works with Brazilian authors. In the first three years, from 2013 to 2015, the percentage of articles with international co-authors increased by $17.5 \%$. On the other hand, in the most recent three years, from 2016 to 2018, there was only a $1.8 \%$ growth (Web of Science Group, 2018). However, only a still relatively small percentage of professors/researchers (about 30\% of the total) maintains systematic interaction and joint production with international partners (Web of Science Group, 2018). These are apparently contradictory aspects of the international integration of the Brazilian academic profession. Nevertheless, it is possible to emphasize the intensity of cooperation and internationalized production as a positive result of the policies developed by the agencies analyzed here.

\section{Final remarks}

Taking Knight and De Wit's definitions as a reference, Brazil has the characteristic features of the internationalization processes: an intentional intensification of the activities and relations of the higher education system with institutions beyond its borders. The presence of indications of these activities on the websites, the well-structured programs of international cooperation and exchange of professors and students, joint degree programs, 
and bilateral training are good examples of this. However, the limitations are also quite clear: the internationalization of HEls occurs mainly through the Postgraduate Programs and Research Groups, through agreements and programs that promote academic cooperation, professor and student mobility, double degrees, joint production etc. Internationalization actions at home are still very incipient, not very proactive, and relatively noninstitutionalized, even though universities have departments or international relations offices for this purpose. Funding agencies such as CAPES, CNPQ and RSFs are fundamental for starting and consolidating the internationalization process of the HEls. It is worth highlighting CAPES' performance, which creates incentives and funding lines to increase the international activities of postgraduate programs.

It should be noted that, while on the postgraduate level there are already joint training efforts, with some discussion of curriculum content, in the case of the undergraduate level, there are no consistent efforts, whether they be to set attractive internal curricula for prospective foreign students, or to prepare Brazilian students for the challenges of international collaboration. In this context, it is necessary to ask: are the conditions which, in other countries, drive university initiatives and governmental internationalization policies present in Brazil? Everything indicates that they are not. The Brazilian higher education system is not a pole of attraction for foreign students and does not depend on these students for its growth. There has been no progress in public policies to attract foreign students in the name of academic or scientific diplomacy conceptions. Vocational training at a higher level still focuses mainly on the local and national labor market, strongly regulated by interference from professional corporations, which is at odds with world trends.

Scientific and technological research is predominantly the result of the work of postgraduate professors and students. The self-sufficiency in the formation of postgraduate professionals, from the constitution of a wide national network of master's and doctorate courses, has generated an active internal audience for the research produced in the country. Only a relatively 
small percentage of professors/researchers (about 30\% of the total) maintains systematic interaction and joint production with international partners.

Similarly, the bodies responsible for national science and technology policies were not able to define priorities or strategies capable of lifting Brazilian groups to the status of world leaders in the production of knowledge. Competition is low, bureaucratic and wage barriers are high when it comes to attracting world-class teachers and researchers. Thus, Brazil lives a kind of paradox: it managed to build a solid system of postgraduate training and academic research but remains weakly integrated into the international flow of scientific and technological knowledge production. It is worth noting that, in both cases, the definition of policies was made by the central government, establishing models and parameters both for postgraduate programs and research and for internationalization. A question remains about the social and institutional conditions that weaken the capacity for agency in most national institutions, especially in the generation of actions towards a more effective integration in international education and research networks.

The still incipient character of the internationalization of the Brazilian higher education system and the quality of the actions developed by the mentioned funding agencies indicate a set of opportunities, more or less explored, that can bring to Brazil the positive side of this process, that is, the strengthening of the system's quality and its contributions to greater equity. Joint training experiences (double degrees) can translate into improvements in curriculum standards. The increase in opportunities for experiences abroad (doctoral stays; research internships etc.) can work to reinforce equality policies. The attraction of new researchers and foreign professors stimulates the updating of the curricula, and contact with students from different national origins encourages multicultural experiences.

The challenges to the internationalization of Brazilian universities are still great and can translate into specific issues: rethinking the university planning giving priority to internationalization; carefully defining the institutional profiles in order to select the appropriate strategic partners; and developing 
own policies for positioning in the new spaces of the world competition for excellence and quality.

There is, therefore, a long way ahead for Brazilian universities towards internationalization at the national level and proactive integration into the global scenario. The greater or lesser success will depend on the adequate coordination of public policies and institutional disposition in the definition of priorities and the relevant promotion instruments.

Clarissa Eckert Baeta Neves is full professor at the Federal University Rio Grande do Sul (UFRGS) in the Graduate Program in Sociology, a CNPq 1A researcher and leader of GEU/ UFRGS the Group of Studies on Universities.

$\triangle$ clarissa.neves@yahoo.com.br

Maria Ligia de Oliveira Barbosa is associate professor at the Federal University of Rio de Janeiro (UFRJ) and leader of LAPES (Higher Education Research Lab/UFRJ/CNPq), Rio de Janeiro, RJ, Brazil.

$\triangle$ mligiaifcs@gmail.com

\section{References}

1. ALTBACH, Philip G.; KNIGHT, Jane. The internationalization of higher education: motivations and realities. Journal of Studies in International Education, v. 11, n. 3-4, p. 290-305, 2007. https://doi.org/10.1177/1028315307303542

2. BERNHEIM, Carlos T. La internacionalización de la educación superior. Significado, relevancia y evolución histórica. In: Gacel-Ávila, Joceline (Org.) Educación superior, internacionalización e integración en América Latina y el Caribe. Balance regional y prospectiva. Caracas: UNESCO - IESALC y Córdoba: Universidad Nacional de Córdoba, 2018. p. 17-40.

3. BRANDENBURG, Uwe; DE WIT, Hans. The end of internationalization. International Higher Education, n. 62, p. 15-17, 2011. https://doi.org/10.6017/ ihe.2011.62.8533

4. BRASIL. Ministério das Relações Exteriores. PEC-G. Histórico do Programa: Introdução. DELP - Divisão de Temas Educacionais (site), 2019a. Available at: http://www.dce.mre.gov.br/PEC/G/historico/introducao.php 
5. BRASIL. Ministério das Relações Exteriores. Programa de Estudantes-Convênio de Pós-Graduação - PEC-PG. DELP - Divisão de Temas Educacionais (site), 2019b. Available at: http://www.dce.mre.gov.br/PEC/PG/historico.php

6. BRASIL. Presidência da República. Decreto no 7.642, de 13 de dezembro de 2011. Institui o Programa Ciência sem Fronteiras. Brasília, 2011. Available at: http://www.planalto.gov.br/ccivil_03/_ato2011-2014/2011/decreto/d7642.htm

7. BUCKNER, Elizabeth. The changing discourse on higher education and the nation-state, 1960-2010. Higher Education, n. 74, p. 473-489, 2017. https://doi. org/10.1007/s10734-016-0056-2

8. CAPES - Coordenação de Aperfeiçoamento de Pessoal de Nível Superior. Infocapes: Boletim Informativo da CAPES. v. 10, n. 4. Brasília: CAPES/MEC, 2002.

9. CAPES - Coordenação de Aperfeiçoamento de Pessoal de Nível Superior. Plano Nacional de Pós-Graduação - PNPG (2011-2020). v.1. Brasília: CAPES, 2010.

10. CAPES - Coordenação de Aperfeiçoamento de Pessoal de Nível Superior. A internacionalização na universidade brasileira: resultados do questionário aplicado pela Capes. Brasília: CAPES/Diretoria de Relações Internacionais, 2017a.

11. CAPES - Coordenação de Aperfeiçoamento de Pessoal de Nível Superior. Programa institucional de Internacionalização - CAPES-Prlnt. CAPES (site institucional), 7 novembro, 2017b. Available at: https://www.capes.gov.br/bolsase-auxilios-internacionais/capes-print

12. CAPES - Coordenação de Aperfeiçoamento de Pessoal de Nível Superior. Seleção projetos institucionais de internacionalização. Edital 41/2017 Capes/ Print. Resultado preliminar da análise de mérito. Brasília: CAPES, 2018. Available at: http://www.capes.gov.br/images/20082018_Edital_41_2017_PrInt_resultado_ parcial_-_análise_de_mérito.pdf

13. COLLINS, Christopher; RHOADS, Robert. The World Bank, support for universities, and asymmetrical power relations in international development. Higher Education, v. 59, n. 2, p. 181-205, 2010. https://doi.org/10.1007/s10734009-9242-9

14. CROSE, Brian. Internationalization of the higher education classroom: strategies to facilitate intercultural learning and academic success. International Journal of Teaching and Learning in Higher Education, v. 23, n. 3, p. 388-395, 2011. http://www.isetl.org/ijtlhe/.

15. CROSS, Di; THOMSON, Simon; SINCLAIR, Alexandra. Research in Brazil: a report for CAPES by Clarivate Analytics. Clarivate Analytics, 2017. Available at: https://www.capes.gov.br/images/stories/download/diversos/17012018-CAPESInCitesReport-Final.pdf.

16. DE WIT, Hans; HUNTER, Fiona; HOWARD, Laura; EGRON-POLACK, Eva. The internationalisation of higher education. Brussels: European Parliament, Committee on Culture and Education, 2015. 
17. DING, Anning; LEVIN, John. The interventionary state in China and programs and curricula at a Chinese vocational university. Higher Education, v. 53, n. 5, p. 539-560, 2007.

18. FAUBAI. Associação Brasileira de Educação Internacional. Sobre a FAUBAI (site institucional), 2019. Available at: http://faubai.org.br/pt-br/.

19. FABRIZI, Andrea; GUARINI, Giulio; MELICIANI, Valentina. Public knowledge partnerships in European research projects and knowledge creation across R\&D institutional sectors. Technology Analysis and Strategic Management, v. 28, n. 9, p. 1056-1072, 2016. https://doi.org/http://www.tandfonline.com/loi/ctas20

20. FRENKEN, Koen; PONDS, Roderick; VAN OORT, Frank. the citation impact of research collaboration in science-based industries: a spatial-institutional analysis. Papers in Regional Science, v. 89, n. 2, p. 351-371, 2010. https://doi.org/http:// onlinelibrary.wiley.com/journal/10.1111/\%28ISSN\%291435-5957/issues

21. FUMASOLI, Tatiana; BARBATO, Giovanni; TURRI, Matteo. The determinants of university strategic positioning: a reappraisal of the organisation. Higher Education, published online 12 dec. 2019. https://doi.org/10.1007/s10734-01900481-6

22. FUMASOLI, Tatiana; HUISMAN, Jeroen. Strategic agency and system diversity: conceptualizing institutional positioning in higher education. Minerva, n. 51, p. 155-169, 2013. https://doi.org/10.1007/s11024-013-9225-y

23. GRANGE, Lesley. The role of (dis)trust in a (trans)national higher education development project. Higher Education, v. 46, n. 4, p. 491-505, 2003. https:// doi.org/10.1023/A:1027351123057

24. HIRD, Mackenzie D.; PFOTENHAUER, Sebastian M. How complex international partnerships shape domestic research clusters: difference-indifference network formation and research re-orientation in the MIT Portugal Program. Research Policy, v. 46, n. 3, p. 557-572, 2017. http://www.sciencedirect. com/science/article/pii/S0048733316301718

25. INEP/MEC - Instituto Nacional de Estudos e Pesquisas Educacionais Anísio Teixeira. Censo da Educação Superior - Divulgação dos Principais Resultados do Censo da Educação Superior 2018. Site institucional INEP, 2018. http://portal. inep.gov.br/web/guest/sinopses-estatisticas-da-educacao-superior.

26. KAUPPINEN, Ilkka Towards transnational academic capitalism. Higher Education, v. 64, n. 4, p. 543-556, 2012. https://doi.org/10.1007/s10734-0129511-x

27. KNIGHT, Jane. Updating the definition of internationalization. International Higher Education, n. 33, p. 2-3, 2003.

28. KNIGHT, Jane. The international university. Models and muddles. In: BARNETT, Ronald; PETERS, Michael A. (Eds). The idea of the university: contemporary 
perspectives. (Global Studies in Education). New York, Brussel: Peter Lang, 2018. p. 99-118.

29. KNIGHT, Jane; DE WIT, Hans. Internationalization of higher education: past and future. International Higher Education, n. 95, p. 2-4, 2018. https://doi. org/10.6017/ihe.2018.95.10715

30. LO, William. The recalibration of neoliberalisation: repoliticising higher education policy in Hong Kong. Higher Education, v. 73, n. 5, p. 759-773, 2017.

31. MAILLARD, Nicolas. $\mathbf{O}$ gestor de relações acadêmicas internacionais no Brasil: práticas, papéis e desafios. SEAD/ UFRGS. Porto Alegre: Editora da UFRGS, 2019.

32. MARGINSON, Simon. The public/private divide in higher education: a global revision. Higher Education, v. 53, n. 3, p. 307-333, 2007. https://doi. org/10.1007/s10734-005-8230-y

33. MARTINS, Carlos Benedito. Notas sobre a formação de um sistema transnacional de ensino superior. Caderno CRH, v. 28, n. 74, p. 291-308, 2015. http://dx.doi.org/10.1590/S0103-49792015000200004

34. MCMANUS, Concepta; NOBRE, Carlos A. Brazilian scientific mobility program - Science without Borders. Preliminary results and perspectives. Anais da Academia Brasileira de Ciências, v. 89, n. 1, p. 773-786, 4 maio 2017.

35. MOK, Ka-Ho. Globalization and educational restructuring: university merging and changing governance in China. Higher Education, v. 50, n. 1, p. 57-88, 2005.

36. MOROSINI, Marília. Apresentação. Dossiê internacionalização da educação superior, Educação, v. 40, n. 3, p. 288-292, 2017. http://dx.doi. org/10.15448/1981-2582.2017.3

37. MWANGIL, Chrystal A. G. et al. Criticality in international higher education research: a critical discourse analysis of higher education journals. Higher Education, n. 76, p. 1091-1107, 2018, https://doi.org/10.1007/s10734-0180259-9

38. NEVES, Clarissa E. B. Higher education systems and institutions, Brazil. In: SHIN, Jung C.; TEIXEIRA, Pedro (Eds.). Encyclopedia of international higher education systems and institutions. Dordrecht: Springer Science+Business Media, 2017. p. 1-13.

39. PAIZ, Rawdhah. Internationalization agenda: language as a barrier. Proceedings Education and Language International Conference, v. 1, n. 1, p. 703-706, 2017.

40. PIRES, Roberto R. C. (Org). Implementando desigualdades. Reprodução de desigualdades na implementação de políticas públicas. Rio de Janeiro: IPEA, 2019. 
41. SCHWARTZMAN, Simon. Um espaço para a ciência: a formação da comunidade científica no Brasil. Brasília: Ministério da Ciência e Tecnologia, 2001.

42. SLAUGHTER, Sheila.; CANTWELL, Brendan. Transatlantic moves to the market: the United States and the European Union. Higher Education, v. 63, n. 5, p. 583-606, 2012. https://doi.org/10.1007/s10734-011-9460-9

43. STALLIVIERI, Luciane. Internacionalização e intercâmbio: dimensões e perceptivas. Curitiba: Appris, 2017.

44. TEICHLER, Ulrich. The changing debate on internationalization of higher education. Higher Education, v. 48, n. 1, p. 5-26, 2004.

45. VIEIRA, Andréa C. Internacionalização da educação superior brasileira: uma nova fase se inicia após o Ciência sem Fronteiras e o Inglês sem Fronteiras? Dissertação (Mestrado em Desenvolvimento, Sociedade e Cooperação Internacional) Centro de Estudos Avançados Multidisciplinares. Universidade de Brasília, 2019.

46. WALKER, Judith. Time as the fourth dimension in the globalization of higher education. The Journal of Higher Education, v. 80, n. 5, p. 483-509, 2009.

47. WEB OF SCIENCE GROUP. A pesquisa no Brasil: promovendo a excelência. Análise preparada para a CAPES pelo Grupo Web of Science. Web of Science Group, 2018.

48. YONEZAWA, Akiyoshi; SHIMMI, Yukiko. Transformation of university governance through internationalization: challenges for top universities and government policies in Japan. Higher Education, v. 70, n. 2, p. 173-186, 2015.

49. ZELEZA, Paul. Internationalisation in higher education: opportunities and challenges for the Knowledge Project in the Global South. In: KOTECHA, P. (Ed.), Internationalisation in Higher Education: perspectives from the Global South. Wits: SARUA, 2012.

50. ZICMAN, Renée. Brazilian Association of International Education (Associação Brasileira de Educação Internacional). In: GACEL-ÁVILA, Jocelyne (Ed.) The international dimension of higher education in Latin America and the Caribbean. Guadalajara: RIESAL-Universidad de Guadalajara, 2018.

Received: 15 Jan. 2020.

Approved: 04 June 2020. 